\title{
Insight \\ Access and Resilience: Analyzing the Construction of Social Resilience to the Threat of Water Scarcity
}

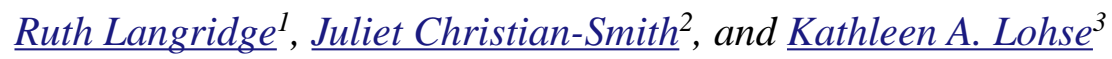

\begin{abstract}
Resilience is a vital attribute that characterizes a system's capacity to cope with stress. Researchers have examined the measurement of resilience in ecosystems and in social-ecological systems, and the comparative vulnerability of social groups. Our paper refocuses attention on the processes and relations that create social resilience. Our central proposition is that the creation of social resilience is linked to a community's ability to access critical resources. We explore this proposition through an analysis of how community resilience to the stress of water scarcity is influenced by historically contingent mechanisms to gain, control, and maintain access to water. Access is defined broadly as the ability of a community to actually benefit from a resource, and includes a wider range of relations than those derived from property rights alone. We provide a framework for assessing the construction of social resilience and use it to examine, first, the different processes and relations that enabled four communities in northern California to acquire access to water, and second, how access contributed to their differential levels of resilience to potential water scarcity. Legal water rights are extremely difficult to alter, and given the variety of mechanisms that can generate access, our study suggests that strengthening and diversifying a range of structural and relational mechanisms to access water can enhance a community's resilience to water scarcity.
\end{abstract}

Key Words: Access; resilience; vulnerability; water

\section{INTRODUCTION}

It is widely acknowledged that resilience is a desirable characteristic of social and ecological systems that confront a variety of stresses (Adger 2000, Gunderson and Holling 2002, Rockstrom 2003, Folke et al. 2004, Klein et al. 2005). Until recently, research focused on the definition and measurement of resilience in social-ecological systems (Holling 1973, 1986, 1995, Ribot 1995, Clark et al. 2000, Gunderson and Holling 2002, Berkes et al. 2002), and the comparative vulnerability of social groups (Watts and Bohle 1993, Ribot 1996, Bohle 2001, Luers 2005). Less attention was paid to the concept of social resilience and, specifically, to the conditions under which it is created. We address this gap by situating social resilience at the center of our inquiry. Complementary to studies that measure social resilience, we propose that an in-depth analysis of the historical processes and relations that create social resilience can better contribute to the development of current policies and practices to enhance social resilience.
Our central proposition is that "the creation of social resilience is linked to a community's ability to access critical resources." We explore this proposition through an analysis of how community resilience to the stress of water scarcity is influenced by historically contingent mechanisms to gain, control, and maintain access to water. Access is defined broadly as the ability of a community to actually benefit from a resource and, most importantly, this definition of access includes a wider range of relations than those derived from property rights alone (Ribot and Peluso 2003). How a community gains, maintains, and controls access to a critical resource can be expressed through an analysis of the means, processes, and relations, or "mechanisms," that facilitate access (Ribot and Peluso 2003), as these are embedded in the social and environmental histories of a region.

First, we integrate research on resilience (Gunderson and Holling 2002, Folke et al. 2002, Berkes et al. 2002), vulnerability (Dreze and Sen 1989, Watts and Bohle 1993, Bohle 2001), and access (Ribot and Peluso 2003) to develop a framework for analyzing the links between access 
and social resilience. Second, we use this framework to map the historically contingent access mechanisms of four communities in northern California to one critical resource, water. Access to water is essential for aquatic and human health and survival, and a secure supply of water must be available in sufficient quantities to sustain communities within a social-ecological system. We contrast three communities in the Russian River watershed and the Round Valley Tribal Reservation in the Eel River watershed, which are all currently competing for the same water resources. In this politically charged atmosphere, we analyze the mechanisms that influence each community's ability to access water, illustrate how access corresponds to differential levels of resilience to water scarcity, and discuss important policy implications.

\section{THEORIES OF RESILIENCE AND ACCESS}

The concept of resilience was initially explored by ecologists (Holling 1973), and then applied to social-ecological systems, as researchers considered its definition and measurement, and linked it to environmental sustainability (Folke et al. 2002). Although diverse definitions and measures of resilience can be found in the literature, two interpretations dominate. One is the speed of recovery from a disturbance (Pimm 1984, Tilman and Downing 1994). The other is the magnitude of a disturbance relative to a threshold that can be absorbed before a system changes its structure by changing the processes and variables that control its behavior (Holling 1995, Gunderson and Holling 2002). Recent studies have explored the dynamics of resilience in social-ecological systems and identified the following as increasing resilience: the prevalence of flexibility and diversity in management regimes (Newman and Dale 2005), the existence of ecological knowledge (Trosper 2004), and of polycentric, multi-layered, and accountable institutions (Lebel et al. 2006) with a capacity for learning (Brooks and Adger 2005, Brooks et al. 2005), and the existence of coalitions, networks, and leadership (Tompkins and Adger 2004, Walker et al. 2006, Olsson et al. 2006, Gunderson et al. 2006). Our paper expands on this research. We suggest that, along with investigating how the resilience of coupled social-ecological systems can be enhanced by different human institutions and management systems (Berkes and Folke 1998, Janssen et al. 2000, Berkes et al. 2002, Rockstrom 2003, Olsson et. al.
2004), it is critical to examine how social resilience is developed, and the full range of mechanisms through which a social community builds the capacity to cope with and adapt to stress.

In addition to research on social-ecological systems, many social scientists have employed the broader concept of vulnerability to examine both the magnitude of a disturbance that a social community can absorb and the likely speed of its recovery when confronted with stress. The degree of vulnerability is depicted as related to both the nature of the stress and the resilience of the system. Stress is considered external to the system and is characterized as a disturbance or shock relative to a threshold, whereas resilience is portrayed as an internal capacity of the system to cope with and adapt to a stress (Adger 2000, Bohle 2001, Luers 2005). Research has associated vulnerability with environmental degradation (Folke et al. 2002), poverty (Sen 1981) and civil strife (Chambers 1989). Current work emphasizes the multiple physical, social, and political-economic causal agents and processes that shape vulnerability (Ribot 1996). Most of these studies remain centered on measuring outcomes using several different analytical frameworks to assess comparative vulnerability, e.g., the risk-hazard (RH) model (Bohle et al. 1994), the pressure-and-release (PAR) model (Blaikie et al. 1994), and the sustainability (SUST) framework (Turner et al. 2003). These models describe general processes that lead to vulnerable people and places (Luers 2005). Yet, research so far has lacked a way to fully theorize, as well as empirically delineate how social resilience is created (Bohle 2001, Adger 2003).

Many of these studies have, however, associated enhanced resilience with an individual's or community's entitlements. Early research by Sen (1981) and Dreze and Sen (1989) focused on why some households and communities are less resilient and suffer greater impacts when confronted with the stress of famine. They posited that vulnerability could be reduced if a household's entitlements were sufficient to enable it to cope with the stress of inadequate food stocks. The observation was that a positive relationship existed between entitlements and the resilience of an individual or community confronted with ecological or economic risks, and social assets such as networks were as important as material goods in reducing vulnerability (Bohle 2001). Watts and Bohle (1993) extended this analysis, embedding entitlements in the political 
economy, where empowerment, or the ability to shape the political economy, in turn shaped entitlements. Ribot and Peluso (2003) expanded the notion of empowerment, pointing to the whole range of powers embodied in and exercised through particular social, economic, and political mechanisms that configured a community's ability to access a resource. We expand on this research to propose that the ability to gain, control, and maintain access to a critical resource amplifies a community's entitlements, creates a buffer during times of scarcity, and increases a community's ability to manage stress. It follows that understanding how resilience is generated requires research into who achieves access, why, and with what impacts. We do this through mapping the patterns of access both spatially and historically across four communities in northern California.

In our analysis, we use Ribot and Peluso's (2003) distinction between "rights" to a resource and the broader concept of "access" to a resource. They describe access as emerging from an expanded array of means, processes, and relations within society, which they coin "mechanisms," that delineate how a community gains, controls, and maintains access. These mechanisms, illustrated in Table 1, include such structural and relational processes as technology, capital, markets, labor, knowledge, authority, identities, and social relations, as well as rights sanctioned by law, custom, or convention. For example, capital can facilitate both the ability to gain and control access to water through the financing of modes of extraction via the construction of a dam or canal that, in turn, can enable the perfection of a water right, and it can help maintain resource access when used to support legal assistance. It can be used to finance the infrastructure necessary to extract and transfer water from one basin to another. Technological expertise can facilitate the construction of infrastructure, including storage and transmission systems that provide physical access to water for particular communities. Social relations can provide links to individuals and institutions with the ability to make and implement laws, as well as to networks of friendships and obligations that can strongly influence the ability to gain and maintain access to the distribution and use of a resource (Ribot and Peluso 2003).

Although Ribot and Peluso locate access in a range of political, economic, and social mechanisms, our framework recognizes that social systems are also embedded in their biophysical environment, therefore, environmental circumstances can affect access. Thus, opportunities for access are facilitated not only by social processes and relations, but also by the geographic location and climate of a region and the ecological integrity of the resource base. In addition, social relations and environmental conditions shift over historical and geographical scales, and the ability to access resources is a complex and dynamic process dependent on specific risks and timescales. Therefore, our approach focuses on one resource:-water; and on a specific risk - a loss of water. This method enables us to provide detailed and local insights while also yielding broader propositions.

\section{CASE STUDIES: ACCESS TO WATER IN THE EEL RIVER AND RUSSIAN RIVER WATERSHEDS, NORTHERN CALIFORNIA}

The following section applies our framework using an empirical analysis of four communities in northern California competing for the same water. A community's cumulative history shapes its particular distribution of assets, and how they are produced and reproduced; and it reveals how differential access to resources is embedded in the broader political economy. To understand how a community's current access to water is generated, and how different forms of access influence a community's resilience in the face of potential water scarcity, it is critical to examine this history. First we provide a brief overview of the biophysical and social context of the region, and then we focus on the four case studies to illuminate important links between access and social resilience. In each case, we 1) describe the conditions under which local access to water occurs, including the different mechanisms used by each community to generate access, and 2) illustrate how shifts in local and nonlocal variables influence the ability to gain, maintain, and control access to water. In our discussion, we map the relationship between each community's forms of access to water, and their differential levels of resilience to water scarcity. Our research results raise additional interesting questions regarding the conditions under which ecosystem resilience is threatened or enhanced by social resilience, and whether access and resilience can be mutually constitutive. Further empirical studies can address these questions, and enable the development of stronger theories of resilience. 
Table 1. Access mechanisms.

\begin{tabular}{ll}
\hline \hline Mechanisms & Water resource-related examples \\
\hline Technology & Ability to construct water supply and distribution systems \\
Capital & Financial assets to construct supply and distribution systems \\
Authority & $\begin{array}{l}\text { Federal law and doctrines (ESA, CWA, reserved rights, prior appropriation), government actors, } \\
\text { water districts and agencies }\end{array}$ \\
Markets & Water sales \\
Identity & Tribe, watershed, county, work (fisherman, farmer) \\
Knowledge & Scientific and legal expertise, traditional ecological knowledge \\
Networks & Lobbying in Sacramento and Washington, D.C., community groups, issue groups \\
\end{tabular}

\section{Biophysical and Social Context}

The four case-study communities, Potter Valley, Redwood Valley, Santa Rosa, and Round Valley Tribes, are located in the Russian River and Eel River watersheds on the north coast of California (Fig. 1), a geographical region characterized by its Mediterranean climate. The Russian River watershed straddles Mendocino and Sonoma Counties. It is roughly $128.75 \mathrm{~km}$ long, drains $3846.13 \mathrm{~km}^{2}$, and has an average annual discharge of 1.6 million acre-feet. In contrast, the Eel River is almost three times the size of the Russian River and has an average annual discharge of 5.4 million acre feet (Langridge 2003). As few large freshwater lakes occur naturally in these regions, and groundwater tends to either be far below the land surface or in thin bands along the stream corridor, people rely heavily on rivers for fresh water (Dietch et al. 2005). The region is characterized by high inter-annual variation in precipitation, with $65-80 \%$ or more of the annual rainfall occurring in winter and in a few large storm events. In addition, annual rainfall between years is highly variable, resulting in periodic droughts.

The seasonal variability of water, as well as the threat of drought, leads to intense competition among different communities for water. This competition is exacerbated by a legal and institutional basis for control over water in
California that separates rights to water from rights to land, and, under the Doctrine of Prior Appropriation, prioritizes those claims that are firstin-time. Appropriation also entails that water be diverted out of a watercourse to demonstrate "beneficial use." A range of water districts and agencies in the state with different degrees of resources and power administer water distribution. The rights to surface water are regulated by the California State Water Resources Control Board (SWRCB), but the federal government has major influence over water allocation through its ability to reserve water for federal reservations including Indian reservations, and through such statutes as the Reclamation Act, the federal Power Act, the Endangered Species Act (ESA), and the Clean Water Act (CWA). Recently, the ESA has placed constraints on the SWRCB to leave more water instream to protect the habitat of endangered species.

The legal and institutional system also facilitated the construction of dams and storage facilities to support municipal growth and large-scale irrigation throughout California, often resulting in significant transfers of water from one river basin to another (Worster 1992, Hundley 2001). The history of access to water in our four communities is directly linked to such an inter-basin transfer via a hydropower project constructed in 1908 . W. W. van Arsdale, the financier who capitalized the initial Potter Valley hydropower project's construction, 
Fig. 1. Eel and Russian River Watersheds (adapted from Friends of the Eel. (online) URL: www.eelriver. org).

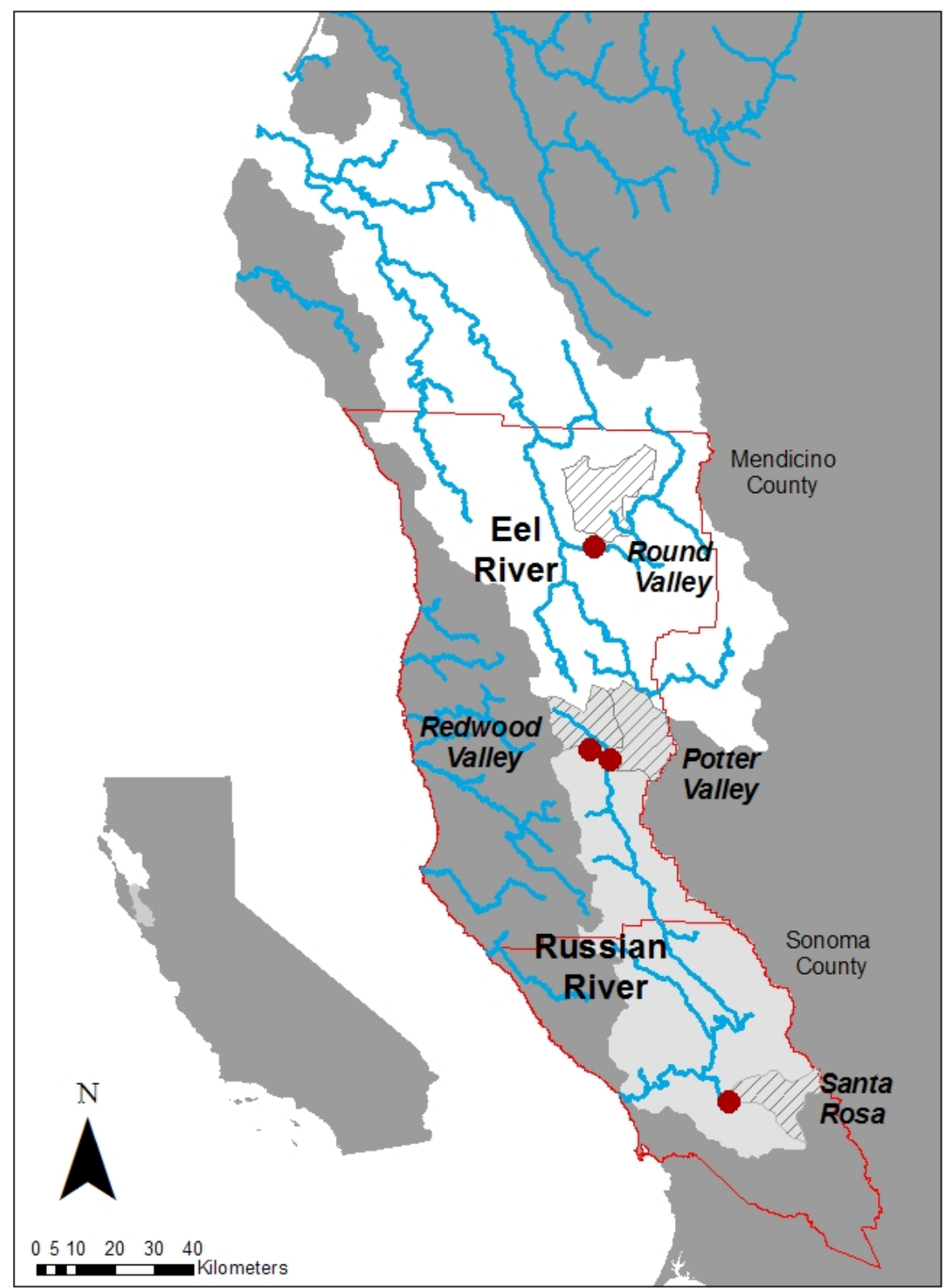


took advantage of a natural mountain divide between the Eel and the Russian River to construct Cape Horn Dam on the Eel River. The dam impounded water and stored it in Van Arsdale Reservoir. The company tunneled through the mountain and dropped the Eel River water into the power plant, located in the Russian River watershed. The imported Eel River water was then released, after use, into the East Fork of the Russian River. A second and larger reservoir on the Eel River, Lake Pillsbury, constructed in 1920, increased the diversion (Fig. 2). The transfer of water from the Eel to the Russian River had a significant impact, creating an abundance of water for the Russian River communities, particularly Potter Valley and Santa Rosa, in the summer and early fall when the Russian River normally dried up. The transfer also created a human-induced scarcity of water for the Eel River and its communities, including the Round Valley Tribes (Langridge 2002).

Today, Santa Rosa and Potter Valley derive a significant amount of their water from the Russian River, which in turn receives its water from the Eel River via this inter-basin transfer. The result for both communities has been a stable supply of water and, along with expanding markets and inexpensive immigrant labor, the transfer has spurred municipal and agricultural development (Langridge 2003). In particular, the southern portion of the Russian River watershed is currently experiencing a boom in suburban and urban development around the city of Santa Rosa. Shifting demographics, as well as new markets and labor, have also resulted in the growth of Redwood Valley, not an original recipient of the Eel River water. The growth and development of these communities contrasts with that of the Eel River-based Round Valley Tribes, who historically have lacked the ability to access their legal water and fishing rights (Langridge 2002).

\section{Potter Valley}

In 1905, when W. W. van Arsdale financed the initial construction of the Potter Valley Hydropower Project (PVP), a new and large source of water imported from the Eel River became available to the rural town of Potter Valley. Although it was already established as a prosperous farming community, this new source of water subsequently enabled Potter Valley to expand its economic base through increased crop production. To gain legitimate access to the water diverted from the Eel
River, in 1924 the town formed the Potter Valley Irrigation District and contracted with the initial owner of the PVP (currently owned by PG\&E) for the water discharged from the hydropower project. This was the first community to gain de facto rights to this new supply of water. Eventually they increased their contracted rights to a total of 2.83 $\mathrm{m}^{3}$ per second $(\mathrm{cms})$ of water per year of PVP discharge, and the district developed a network of irrigation canals to distribute the water to farmers. Thus, Potter Valley gained access to Eel River water both through contracted rights and the capital and technology needed to construct irrigation canals (Langridge 2002).

However, the district's rights-based access lacked security due to a 1939 ruling by the California Supreme Court, Stevens vs. Oakdale Irrigation District, which held that the importer of a supply of water from outside the watershed could discontinue it at any time. Thus, if the project were sold to a party who chose to decommission it, or if the federal government chose not to re-license the project in 2022, Potter Valley would have little legal recourse to keep the water flowing from the Eel to its canals. A second concern for Potter Valley was the geological character of the valley, with a fractured aquifer that holds only a limited quantity of water as backup storage for irrigation (R. Curry, unpublished material).

In 1990, Eel River salmonids were listed as threatened under the federal Endangered Species Act (ESA). This necessitated reducing the flow of water from the Eel River to the Russian River to avoid "jeopardy" (detailed in Section 7 of the ESA), threatening Potter Valley's access to some of the water from the Eel. In response, Potter Valley residents formed the Mendocino County Inland Water and Power Commission (MCIWPC) in 1996 as a coalition of upper Russian River interests based in Mendocino County (MCIWPC, unpublished material). Their goal was to keep the Eel River water flowing, as well as to fend off a "water grab" from its southerly neighbor, the Sonoma County Water Agency (SCWA), who was negotiating to purchase the project. The Executive Director of the Inland Water and Power Commission, spouse of the former president of the California Farm Bureau, played an active role in this process. Through its charter, the commission ensured that it would have the first opportunity to act as the lead on any future water developments in the county, thus gaining increased authority to control access to the diverted water. 
Fig. 2. The Potter Valley Project.

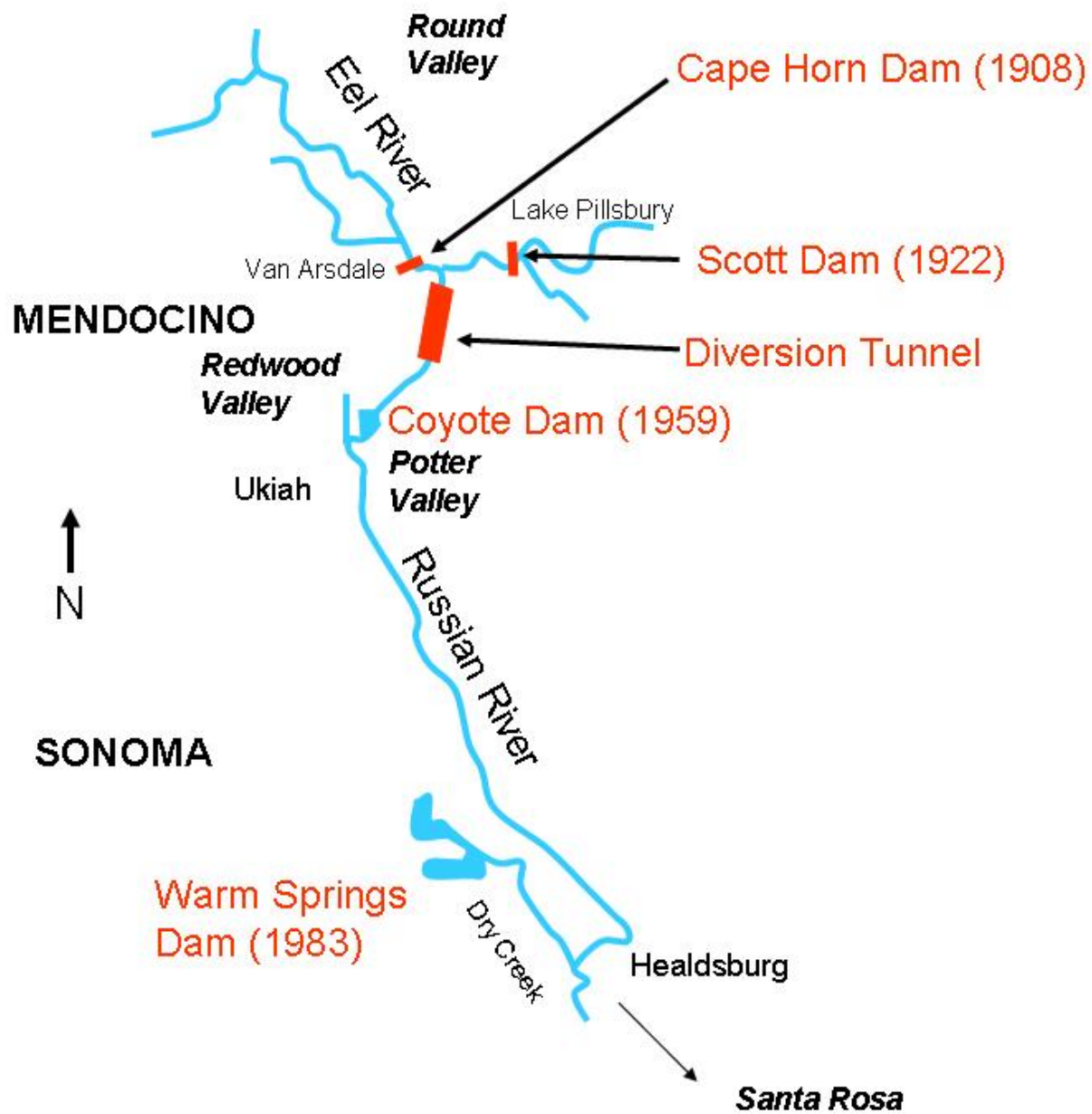

In summary, Potter Valley benefited from the historic positioning of the PVP, and its contracted water rights assured a steady and reliable supply of water. It developed strong social capital through community networks and successfully and strategically organized its agricultural community to secure a stable water supply. This resulted in the growth and profitability of agriculture in the area. In response to current threats to reduce the imported water, the formation of the commission led by the politically connected executive director, marked a shift from primarily rights-based access mechanisms via contracts and centered in the local district, to access through the mechanisms of authority and social relations via a broader and potentially more powerful coalition of interests. One can map the structural and relational mechanisms used to access water in this case. Technology, capital, social relations, and authority all contributed to the community's present capacity to gain and control access to water. However, the possibility of some water being returned to the Eel, and the future possibility of project decommissioning, mean that maintaining access over the long term is insecure. 


\section{Redwood Valley}

Redwood Valley, a sub-watershed of the Russian River, provides a contrasting case. The Redwood Valley County Water District was not established until the 1970s. It was intended to provide water to farmers in a growing, low-density, rural, residential area just north of the county seat of Ukiah. The district first built a small storage pond that had only enough water to provide several days of frost protection for crops in the valley. The district later obtained winter water rights (which are relatively useless, as winter is also the rainy season) and provisional summer rights to surplus Eel River water stored in Lake Mendocino. These provisional rights stipulate that Lake Mendocino must be above the "beneficial" water level for the district to pump surplus water into their system. Thus, during the summer months, the district has limited rights-based access.

In response to these uncertainties in supply, the Redwood Valley County Water District diversified its mechanisms to obtain access to water. One strategy has been to access water via groundwater pumping during the summer months. Groundwater remains unregulated in California, therefore, developing groundwater pumping capacity represented a shift from rights-based mechanisms to access through technology and capital (needed to locate and drill wells). Although this created additional opportunities, it was often insufficient to meet the demand. Therefore, the district also resorted to access through markets-buying and trucking in water from other areas, which is an expensive and undesirable alternative. The district also attempted to broker access through social relations, engaging in negotiations to form water-sharing agreements, which were ultimately unsuccessful. Today, the Redwood Valley area is under a growth moratorium mandated by the Department of Health Services (DHS) because of a lack of adequate drinking water supplies. The DHS report states: "[Water] users in the Ukiah Valley (including Redwood Valley County Water District... are dependent upon the continued diversion of Eel River to the East Fork of the Russian River since this represents its only reliable source of summer time flow in the river. The potential loss or reduction of this source of supply will have significant impact on the reliability of water supplies" (DHS 2002).

In summary, in contrast to Potter Valley, the Redwood Valley County Water District was disadvantaged by the lack of historic rights-based access. Although it attempted to overcome its earlier disadvantages, the district was unable to increase its control or maintain access to water resources in the area through other structural and relational mechanisms. In particular, the district still lacks capital (small operating budget), authority, and social relations (unable to broker arrangements with other water districts). As rights-based access is further limited, Redwood Valley will have a greater incentive to use additional mechanisms to gain access.

\section{Santa Rosa}

One hour north of San Francisco, and 1 hour south of Potter Valley and Redwood Valley, lies the city of Santa Rosa. Although once mainly an agricultural area, Santa Rosa is now a rapidly expanding urban and suburban metropolis. Early access to water contributed to the city's large-scale growth. Central to this access was the SCWA. The Sonoma County Board of Supervisors and the SCWA's Board of Directors are identical, thus Santa Rosa, as the largest city in the county, has significant input into water policies. The SCWA was established in 1949, when it joined with the Army Corps of Engineers to construct Coyote Dam on the Russian River to capture the imported Eel River water. The water agency raised significant local and federal capital to contribute to the cost of the project and, in return, received rights to $80 \%$ of the water impounded behind the dam in Lake Mendocino, thereby gaining significant control of water resources in the Russian River. From the beginning, the agency's goal was to sell this water both locally as well as to more distant areas (Beach 2002). The agency has continued to gain more water via ongoing applications to the State Water Board for the water stored in Lake Mendocino. It has also attempted to solidify its control over and access to the imported Eel River water through efforts to purchase the Potter Valley Project (Langridge 2003). In 1959, Santa Rosa was the first city to contract with the water agency and still receives all its surface water supplies from it. Santa Rosa's reliable and secure access to water has contributed to its prodevelopment policies, and today it is one of the most rapidly growing cities in northern California.

The 1960s were the heyday of dam building and the growth of powerful water agencies throughout California. In Sonoma County, a series of water 
works and engineering projects funded through revenue from water sales and taxes levied on newly created flood control districts expanded the power of the SCWA. In the 1960s, it lobbied heavily to obtain federal money to construct another dam and reservoir on the West Fork of the Russian River that would be independent of the imported Eel River water. It was designed to provide 212000 acre-feet of additional water supply storage. Congress authorized the dam in 1962, however, there was significant opposition and it was not constructed until 1983. Although the new dam provided additional secure water for the agency, including its largest contractor-the city of Santa Rosaopposition to the dam generated a local movement to reduce the agency's power and reduce growth in the area, and that movement remains active (Langridge 2003). Nevertheless, today the SCWA is the largest water purveyor in northern California, with an annual budget of approximately $\$ 170$ million and a staff of over 60 (University of California Cooperative Extension 2004).

Santa Rosa's ability to benefit from water resources is characterized by structural and relational mechanisms. Santa Rosa used markets, capital, and social relations to gain and maintain access. The city's water rights are contractual, but because the city and the agency share the same Board of Directors, these rights are very secure. Should water be reduced in Lake Mendocino, the agency can turn to the still untapped Warm Springs reservoir to augment supply. Although the city's contract for water has to be renewed periodically, the relationship between city and agency has no serious contingencies.

\section{Round Valley Tribes}

In the remote Round Valley at the confluence of the Middle Fork and the main stem of the Eel River lies the Round Valley Reservation, created in 1870 by an order of President Ulysses S. Grant and affirmed by Congressional statute in 1873 . The statute formally established the boundaries for the Reservation and specifically reserved fishing rights in the Eel River. Both water and fishing rights were sanctioned by the courts as early as 1905 (U.S. vs. Winans 1905, Winters vs. U.S. 1908), but lack of any internal resources limited the tribes' ability to fight for their water and fisheries. Equated to a concentration camp, the Round Valley Reservation was isolated, impoverished, held captive to local white settlers for most of the $20^{\text {th }}$ century, and unable to press for their claims to Eel River water (Langridge 2003).

The struggle of Indian tribes to regain autonomy and resources was long and difficult, and continues today. However, changes occurred after the 1960s as the Indian movement for self-determination and self-governance, as well as the "war on poverty," led to new federal spending that facilitated the development of Indian-led institutions, including California Indian Legal Services (CILS), and provided additional capital to individual tribes (Gross 1989). This enabled the Round Valley Tribes to hire an attorney to initiate a new and intensified effort to reclaim their water rights. They became active participants in the push to divert less water from the Eel River that dominated the extension of the re-licensing process of the Potter Valley Project. Despite the objections of PG\&E, their efforts led to the installation a \$16 million fish screen on Cape Horn Dam to block salmon and steelhead from being sucked into the powerhouse tunnel. A Clinton "Memorandum on Government-to-Government Relations with Native Americans" (1994) that required all federal agencies to consult with tribes regarding any actions that would affect their water and fishing rights, also aided the tribes. They hired their own biologists to research how to restore endangered salmon and formed a coalition with the Department of the Interior via the Bureau of Indian Affairs. Their efforts resulted in a model that maximized water flows down the Eel River to protect endangered species, and which was essentially adopted by all the federal agencies. In the 1990s, the tribes received several major grants to develop a comprehensive water plan for the reservation, including the training of tribal members in water resource management (S. V. Quesenberry, pers. comm. 2003). Thus, the tribes have recently gained some ability to benefit from their legal rights through structural and relational mechanisms. They benefited from new capital that enabled them to hire legal and scientific consultants, and from legal shifts that provided entry to authority in the form of government agencies and the decision-making process. The result was an increase in their ability to access more water in the future. 


\section{DISCUSSION}

Our analysis of the links between access and resilience requires a map of the ability of each community to gain, control, and maintain access to water against the community's ability to cope under the stress of reduced water availability. This is displayed in Table 2. It is important to note that we do not propose direct causality between access and resilience in this analysis. Instead, our intent is to illuminate how community resilience, or the "capacity" to cope with and adapt to water scarcity, is influenced by historically contingent mechanisms to gain, control, and maintain access, factors that are generally not captured by quantitative models.

A water shortage could occur under several stress scenarios. The first entails the strong restrictions imposed by the ESA. The listing of salmonids under the ESA in the Eel River recently mandated that some of the previously diverted water remain in the Eel, which would reduce the flow into the Russian River. The listing of salmonids in the Russian River will place additional restrictions on local diverters in that watershed. The second scenario involves the possible decommissioning of the Potter Valley Project when it comes up for re-licensing in 2022. Because the PVP currently provides an extremely small percentage of PG\&E's total power supply, the project is marginally profitable for energy production. Finally, the region could undergo a severe climatic drought. Although Mediterraneanclimate regions are characterized by seasonal variability, including both flooding and drought, a severe drought would lie outside the normal range of variability and involve drastically reduced precipitation and stream flow over an extended time for both rivers.

As described earlier, Potter Valley's unique geography and history allowed it to gain early access to water through contractual rights. Over time, it used various mechanisms to maintain and control access, including capital, technology, social relations, and authority. Yet, Potter Valley's rightsbased access relies on imported water from the Eel River. Any of the three scenarios would result in increasing flows down the Eel, which would reduce water flows to Potter Valley. Anticipating such a scenario, Potter Valley drew on its significant financial assets and networks and joined with surrounding communities to form the Inland Water and Power Commission. The Commission employed a top water-rights attorney to argue for their customary claims to water. Despite several strong options to cope with the stress of a water shortage, their access remains contingent due to a lack of secure legal rights to the diverted water.

Redwood Valley's main access is through provisional rights to surplus water in Lake Mendocino. Should water flows be reduced under the three scenarios, surplus water would become unavailable. Redwood Valley could use illegal mechanisms (which it has been accused of previously through litigation) or pursue alternative strategies to access water. Yet, it will be impeded by its lack of capital, markets, and authority. Thus, its historical and social histories confer few alternative options, and afford little resilience to the stress of reduced water.

Santa Rosa is in the most secure position. The city is closely linked to the powerful SCWA through their representation on the County Board of Supervisors whose members are identical to the SCWA's Board of Directors. The SCWA's early and vast rights-based and structural and relational mechanisms confer a high capacity to cope with a water shortage. If drought, ESA restrictions, or the decommissioning of the Potter Valley Project significantly decreased water levels in Lake Mendocino, the agency and the city of Santa Rosa through its contract with the SCWA, would still have access to over 200000 acre-feet of currently unused water in Lake Sonoma. Santa Rosa's link to the SCWA, and the agency's cumulative strategies, have thus created a high resilience for the city should any of these three stress scenarios occur.

The Round Valley Reservation presents an interesting case. The tribes hold federally reserved rights to Eel River water, but have historically been unable to benefit from access to this water. After a long period of disenfranchisement, the tribes are beginning to gain the ability to benefit from their "paper rights." Their identity with the Indian movement for self-determination, a more open consultation process with federal agencies, and new resources have enabled them to finally participate in the negotiations over the diverted water. They have hired excellent legal and scientific consultants and successfully pushed for increased flows down the Eel. Their success was also due to links with a broader network of other Eel River activists working to restore the Eel and eventually remove the diversion altogether. 
Table 2. Access and resilience.

\begin{tabular}{|c|c|c|c|c|}
\hline Case Studies & Potter Valley & Redwood Valley & Santa Rosa & Round Valley Tribes \\
\hline \multicolumn{5}{|c|}{ Mechanisms to Access Water } \\
\hline Rights-based & $\begin{array}{l}\text { Early contractual rights } \\
\text { for "abandoned" water } \\
\sim 20000 \mathrm{ac}-\mathrm{ft} / \mathrm{yr}\end{array}$ & $\begin{array}{l}\text { Extremely limited rights } \\
\text { to "surplus" water }\end{array}$ & $\begin{array}{l}\text { Contractual rights } 29100 \\
\text { ac-ft/yr }\end{array}$ & $\begin{array}{l}\text { Federally reserved water } \\
\text { and fishing rights }\end{array}$ \\
\hline Physical form & $\begin{array}{l}\text { Gravity-fed irrigation } \\
\text { canals }\end{array}$ & $\begin{array}{l}\text { Small storage pond } \\
\text { Surface water pumping } \\
\text { Groundwater pumping }\end{array}$ & $\begin{array}{l}\text { Two large reservoirs } \\
\text { Surface water pumping }\end{array}$ & $\begin{array}{l}\text { Unable to physically } \\
\text { access their "paper" } \\
\text { rights }\end{array}$ \\
\hline Technology & Potter Valley Project & Limited & $\begin{array}{l}\text { SCWA water supply and } \\
\text { distribution system }\end{array}$ & Limited \\
\hline Capital & Extensive & Limited & Extensive & Limited \\
\hline Markets & Sells water & Buys water & Buys water & $\begin{array}{l}\text { No market transactions } \\
\text { involving water }\end{array}$ \\
\hline Social networks & Strong on a local scale & Limited & $\begin{array}{l}\text { Strong on a regional and } \\
\text { state scale }\end{array}$ & Limited \\
\hline Authority & $\begin{array}{l}\text { Inland Water \& Power } \\
\text { Commission has the } \\
\text { right-to-first-refusal on } \\
\text { new water projects in } \\
\text { Mendocino County }\end{array}$ & Limited & $\begin{array}{l}\text { County Board of } \\
\text { Supervisors is also the } \\
\text { SCWA Board of Directors, } \\
\text { ensuring that Santa Rosa } \\
\text { interests will be protected }\end{array}$ & $\begin{array}{l}\text { Status as a sovereign } \\
\text { nation confers access to } \\
\text { tribal legal assistance }\end{array}$ \\
\hline \multicolumn{5}{|c|}{ Potential Resilience } \\
\hline & $\begin{array}{l}\text { Contingent on its } \\
\text { ability to maintain the } \\
\text { diversion and/or gain } \\
\text { access to other water } \\
\text { sources }\end{array}$ & $\begin{array}{l}\text { Limited as it has no } \\
\text { secure forms of access }\end{array}$ & $\begin{array}{l}\text { Robust as it has multiple, } \\
\text { extensive, and secure } \\
\text { forms of access }\end{array}$ & $\begin{array}{l}\text { Contingent on its } \\
\text { ability to maintain } \\
\text { access to legal resources }\end{array}$ \\
\hline
\end{tabular}

\section{POLICY IMPLICATIONS}

The case studies above illuminate important links between access and social resilience. Together they suggest that an understanding of the politics of access, rather than the time it takes to recover from a stress, is critical for policy makers attempting to enhance resilience to the stress of water scarcity.
The examination of the historically contingent and dynamic mechanisms in our four study sites in the Russian-Eel River system reveals that Santa Rosa, with its multiple, overlapping, and secure forms of both rights-based and structural and relational mechanisms, is the only community with a strong capacity to successfully cope with water scarcity. Even though the community of Potter Valley is relatively wealthy, politically connected, and holds 
early contracted water rights in the Russian River basin, the contingent nature of its rights leaves it much less resilient to the stress of reduced water. The Round Valley Tribes have the most secure form of legal water rights available, federal reserved rights, but their level of resilience depends on access to authority, which is significantly influenced by shifting government attitudes toward Indian tribes. Also, despite gains, their overall lack of capital makes them less able to cope with ongoing and powerful pressures to keep the water flowing into the Russian River. Nevertheless, they have made some significant strategic gains, and their capacity may increase in the future. Finally, although Redwood Valley exhibits the least resilience, this lack has encouraged internal development. Therefore, its capacity to cope may also increase in the future.

The distribution of benefit across our study sites reveals significant inequities in capacity to cope with water scarcity. Only Santa Rosa has secure access to a stable water supply. The dominance of the SCWA and Santa Rosa comes at a major cost to the other areas. The Round Valley Tribes are particularly disadvantaged by the diversion of water from the Eel River, but Redwood Valley and Potter Valley also lack security due in large part to the hegemonic status of the SCWA. Thus, benefits are distributed extremely unevenly in the region. Although Santa Rosa represents the largest population, it has a wide range of access mechanisms to meet the demands of that population. Given the variety of mechanisms that can generate access, our study suggests that by moving away from a focus on legal rights toward strengthening and diversifying the full array of structural and relational access mechanisms, social resilience may be increased throughout the region.

Responses to this article can be read online at: http://www.ecologyandsociety.org/voll1/iss2/art18/responses/

\section{Acknowledgments:}

We would like to thank the Mediterranean Watersheds workgroup at the University of California, Berkeley, where some of these ideas originated. This interdisciplinary forum was organized by Adina Merenlender. In addition, we are obliged to Nancy Peluso, Jeff Romm, Adina
Merenlender, and Kate O'Neill who reviewed and commented on early drafts.

\section{LITERATURE CITED}

Adger, W. N. 2000. Social and ecological resilience: are they related? Progress in Human Geography $\mathbf{2 4}$ (3):347-364.

Adger, W. N. 2003. Social capital, collective action and adaptation to climate change. Economic Geography 79(4):387-404.

Beach, R. 2002. History of the development of the water resources of the Russian River. Sonoma County Water Agency, Santa Rosa, California, USA.

Berkes, F., J. Colding, and C. Folke. 2003. Navigating social-ecological systems: building resilience for complexity and change. Cambridge University Press, Cambridge, UK.

Berkes, F., and C. Folke. 1998. Linking social and ecological systems for resilience and sustainability. Pages 1-25 in F. Berkes, C. Folke, and J. Colding, editors. Linking social and ecological systems: management practices and social mechanisms for building resilience. Cambridge University Press, Cambridge, UK.

Blaikie, P., T. Cannon, and I. Davis. 1994. At risk: natural hazards, people's vulnerability and disaster. Routledge, London, UK; New York, New York, USA.

Bohle, H. G. 2001. Vulnerability and criticality: perspective from social geography. Newsletter of the International Human Dimensions Programme on Global Environmental Change 1(2). [online] URL: http://www.ihdp.uni-bonn.de/html/publications/ update01 02/IHDPUpdated01 02bohle.html.

Bohle, H. G., T. E. Downing, and M. J. Watts. 1994. Climate change and social vulnerability: toward a sociology and geography of food insecurity. Global Environmental Change 4:37-48.

Brooks, N., and W. N. Adger. 2005. Assessing and enhancing adaptive capacity. Pages 165-181 in B. Lim and E. Spanger-Siegfried, editors. Adaptation 
policy frameworks for climate change: developing strategies, policies and measures. UNDP-GEF, Cambridge University Press, Cambridge, UK.

Brooks, N., W. N. Adger, and M. Kelly. 2005. The determinants of vulnerability and adaptive capacity at the national level and the implications for adaptation. In W. N. Adger, N. Arnell, and E. L. Tompkins, editors. Adaptation to climate change: perspectives across scales. Global Environmental Change 15(Part A):151-162.

California Department of Health Services. 2002. Drinking water adequacy assessment: Ukiah Valley, Mendocino County. Drinking Water Field Operations Branch, Mendocino District, California, USA.

Chambers, R. 1989. Vulnerability, coping and policy. Institute of Development Studies Bulletin 20:1-7.

Clark, W. C., J. Jager, R. Corell, R. Kasperson, J. McCarty, D. Cash, S. Cohen, P. Desanker, N. Dickson, P. Epstein D. Guston, J. Hall, C. Jawger, A. Janetos, N. Leary, M. Levy, A. Luers, M. MacCracken, J. Melilo, R. Moss, J. Nigg, M. Parry, E. Parson, J. Ribot, H. Schelnjuber, G. Seielstad, E. Shea, C. Vogel, and T. Wilbanks. 2000. Assessing vulnerability to global environmental risks: report of a workshop on global environmental change-challenges for research, assessment and decision making. Research and Assessment Systems for Sustainability Science Program, Discussion Paper 2000-12, Cambridge, Massachusetts, USA.

Clinton, W. J. 1994. Memorandum on governmentto-government relations with native american tribal governments. U.S. Federal Register, Vol. 59, No. 85. U.S. Government, Washington, D.C., USA.

Dietch, M., G. M. Kondolf. and A. M. Merenlender. 2005. Evaluating ecological effects of small-scale agricultural diversions on stream flow in coastal California. North American Benthological Society Conference, 22-27 May 2005, New Orleans, Louisiana, USA.

Dreze, J., and A. Sen. 1989. Hunger and public action. Clarendon Press, Oxford, UK.

Folke, C., S. R. Carpenter, T. Elmqvist, L. H. Gunderson, C. S. Holling, and B. Walker. 2002. Resilience and sustainable development: building adaptive capacity in a world of transformations. Ambio 31(5):437-40.

Folke, C., S. R. Carpenter, B. H. Walker, M. Scheffer, T. Elmqvist, L. H. Gunderson, and C. S. Holling. 2004. Regime shifts, resilience, and biodiversity in ecosystem management. Annual Review of Ecology, Evolution and Systematics 35:557-581.

Gunderson, L. H., S. R. Carpenter, C. Folke, P. Olsson, and G. D. Peterson. 2006. Water RATs (resilience, adaptability, and transformability) in lake and wetland social-ecological systems. Ecology and Society 11(1): 16. [online] URL: http: //www.ecologyandsociety.org/vol11/iss1/art16/.

Gunderson, L. H., and C. S. Holling, editors. 2002. Panarchy: understanding transformations in human and natural systems. Island Press, Washington, D.C., USA.

Harris, C., J. McLaughlin, and G. Brown. 1998. Rural communities in the interior Columbia Basin: how resilient are they? Journal of Forestry 96 (3):11-15.

Holling, C. S. 1973. Resilience and stability of ecological systems. Annual Review of Ecology and Systematics 4:1-23.

Holling, C. S. 1986. The resilience of terrestrial ecosystems; local surprise and global change. Pages 292-317 in W. C. Clark and R. E. Munn, editors. Sustainable development of the biosphere. Cambridge University Press, Cambridge, UK.

Holling, C. S. 1995. What barriers? What bridges? Pages 14-16 in L. H. Gunderson, C. S. Holling, and S. S. Light, editors. Barriers and bridges to the renewal of ecosystems and institutions. Columbia University Press, New York, New York, USA.

Hundley, N. 2001. The great thirst: Californians and water a history. University of California Press, Berkeley, California, USA.

Janssen, M. A., O. Bodin, J. M. Anderies, T. L. Elmqvist, H. Erstson, R. R. J. McAllister, P. Olsson, and P. Ryan. 2006. Toward a network perspective of the study of resilience in socialecological systems. Ecology and Society 11(1): 20. (online) URL: http://www.ecologyandsociety.org/vol11/ iss1/art20/. 
Klein, R., W. W. Dougherty, M. Alam, and A. A. Rahman. 2005. Technology to understand and manage climate risks. Background Paper, United Nations Framework Convention on Climate Change Secretariat, Bonn, Germany.

Langridge, R. 2002. Changing legal regimes and the allocation of water between two northern California rivers. Natural Resources Journal 42 (2):283-330.

Langridge, R. 2003. Negotiating contentious claims to water: shifting dynamics for the allocation of water between two California rivers. Dissertation, University of California, Berkeley, Berkeley, California, USA.

Lebel, L., J. M. Anderies, B. Campbell, C. Folke, S. Hatfield-Dodds, T. P. Hughes, and J. Wilson. 2006. Governance and the capacity to manage resilience in regional social-ecological systems. Ecology and Society 11(1): 19. [online] URL: http: //www.ecologyandsociety.org/vol11/iss1/art19/.

Luers, A. 2005. The surface of vulnerability: an analytical framework for examining environmental change. Global Environmental Change 15:214223.

Newman, L. L., and A. Dale. 2005. Network structure, diversity, and proactive resilience building: a response to Tompkins and Adger. Ecology and Society 10 (1): r2. [online] URL: http: //www.ecologyandsociety.org/vol10/iss1/resp2/.

Olsson, P., C. Folke, and T. Hahn. 2004. Socialecological transformation for ecosystem management: the development of adaptive co-management of a wetland landscape in southern Sweden. Ecology and Society 9(4): 2. [online] URL: http://www.ecol ogyandsociety.org/vol9/iss4/art2/.

Olsson, P., L. H. Gunderson, S. R. Carpenter, P. Ryan, L. Lebel, C. Folke, and C. C. Holling. 2006. Shotting the rapids: navigating transitions to adaptive governance of social-ecological systems. Ecology and Society 11(1): 15. (online) URL: http: //www.ecologyandsociety.org/vol11/iss1/art15/.

Pimm, S. L. 1984. The complexity and stability of ecosystems. Nature 307(26):321-326.

Ribot, J. 1995. The causal structure of vulnerability: its application to climate impact analysis. GeoJournal 35(2):119-122.

Ribot, J. 1996. Climate variability, climate change and social vulnerability: moving forward by looking back. Pages 1-10 in J. C. Ribot, A. R. Magalhaes, and S. Panagides, editors. Climate variability, climate change and social vulnerability in the semiarid tropics. Cambridge University Press, Cambridge, UK.

Ribot, J., and N. L. Peluso. 2003. A theory of access. Rural Sociology 68(2):153-181.

Rockstrom, J. 2003. Resilience building and water demand management for drought mitigation. Physics and Chemistry of the Earth 28(20-27):869877.

Sen, A. 1981. Famines and poverty. Oxford University Press, London, UK.

Tilman, D., and J. Downing. 1994. Biodiversity and stability in grasslands. Nature 367:363-365.

Tompkins, E. L., and W. N. Adger. 2004. Does adaptive management of natural resources enhance resilience to change? Ecology and Society 9(2): 10. (online) URL: http://www.ecologyandsociety.org/vol9/ iss $2 / \operatorname{art} 10$.

Trosper, R. L. 2004. Policy transformations in the U.S. forest sector, 1970-2000: implications for sustainable use and resilience. Pages 328-351 in F. Berkes, J. Colding, and C. Folke, editors, Navigating social-ecological systems. Building resilience for complexity and change. Cambridge University Press, Cambridge, UK.

Turner, B., P. Matson, J. McCarthy, R. Corell, C. Lindsey, N. Eckley, G. Hovelsrud-Broda, J. Kasperson, R. Kasperson, A. Luers, M. Martello, S. Mathieson, R. Naylor, C. Polsky, A. Pulsipher, A. Schiller, H. Selin, and N. Tyler. 2003. A framework for vulnerability analysis in sustainability science. Proceedings of the National Academy of Sciences 100(14):8074-8079.

University of California Cooperative Extension. 2004. Mendocino County Water Agency situational analysis. Mendocino County Cooperative Extension, California, USA. [online] URL: http://cemendocino. ucdavis.edu/Watershed\%2DNatural\%5FResources/ 
Walker, B. H., S. R. Carpenter, J. M. Anderies, N. Abel, G. S. Cumming, M. A. Janssen, L. Lebel, J. Norberg, G. D. Peterson, and R. Pritchard. 2002. Resilience management in social-ecological systems: a working hypothesis for a participatory approach. Conservation Ecology 6(1): 14. [online] URL: http://www.consecol.org/vol6/iss 1/art14.

Walker, B. H., L. H. Gunderson, A. P. Kinzig, C. Folke, S. R. Carpenter, and L. Schultz. 2006. A handful of heuristics and some propositions for understanding resilience in social-ecological systems. Ecology and Society 11(1): 13. (online) URL: http://www.ecologyandsociety.org/vol11/iss1/ art13/.

Watts, M. J., and H. G. Bohle. 1993. The space of vulnerability: the causal structure of hunger and famine. Progress in Human Geography 17(1):4367.

Worster, D. 1992. Rivers of empire: water, aridity, and the growth of the American West. Oxford University Press, New York, New York, USA. 